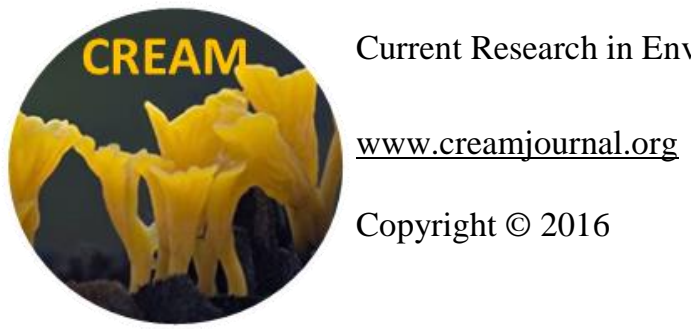

ISSN 2229-2225

Article

CREAM

Doi 10.5943/cream/6/1/3

Online Edition

\title{
Three Quinine and Cinchonidine producing Fusarium species from Indonesia
}

\author{
Hidayat $\mathbf{I}^{1^{*}}$, Radiastuti $\mathrm{N}^{2}$, Rahayu $\mathbf{G}^{3}$, Achmadi $\mathrm{S}^{4}$, Okane $\mathbf{I}^{5}$ \\ ${ }^{1}$ Microbiology Division, Research Center for Biology, Indonesian Institute of Sciences (LIPI), Indonesia, Phone:+62-21- \\ 8765067, Fax: +62-21-8765062 \\ ${ }^{2}$ Biology Department, Faculty of Science and Technology, UIN Syarif Hidayatullah, Indonesia \\ ${ }^{3}$ Biology Department, Faculty of Mathematics and Natural Sciences, Bogor Agricultural University (IPB), Indonesia \\ ${ }^{4}$ Chemistry Department, Faculty of Mathematics and Natural Sciences, Bogor Agricultural University (IPB), Indonesia \\ ${ }^{5}$ Faculty of Life and Environmental Sciences, University of Tsukuba, Japan
}

Hidayat I, Radiastuti N, Rahayu G, Achmadi S, Okane I 2016 - Three Quinine and Cinchonidine producing Fusarium species from Indonesia. Current Research in Environmental \& Applied Mycology 6(1), 20-34, Doi 10.5943/cream/6/1/3

\begin{abstract}
Five endophytic Fusarium isolates from Cinchona calisaya were characterized for their ability to produce cinchona alkaloids, such as quinine, quinidine, cinchonine and cinchonidine. Based on molecular identification using phylogenetic analysis of DNA sequence generated from the internal transcribed spacer (ITS) rDNA and the partial elongation factor $(\mathrm{EF} 1-\alpha)$ gene regions, these isolates were determined as $F$. incarnatum (strain IPBCC 15.1251 and IPBCC 15.1253), F. solani (strain IPBCC 15.1248 and IPBCC 15.1249) and $F$. oxysporum (strain IPBCC 15.1250). All strains, except $F$. solani strain IPBCC 15.1248, were detected capable in producing quinine and cinchonidine by using HPLC and UV-vis spectroscopy analyses. Only quinine was detected from the extract of the $F$. solani strain IPBCC 15.1248. This is the first report of Fusarium species capable of producing quinine and cinchonidine in synthetic liquid medium.
\end{abstract}

Key words - endophyte - fungi - malaria - phylogenetic - cinchona alkaloids

\section{Introduction}

Fusarium Link is an anamorphic hypomycetous fungus linked to Gibberella Sacc. as its teleomorphic state. The member of Fusarium is cosmopolitan found as saprobe, airborne, soilborne, endophyte and plant pathogen on a wide range of host plants, including several economically important crops such as tomatoes (Ignjatov et al. 2012), banana (Dita et al. 2010), cereals (Voigt et al. 2005), etc. Although member of Fusarium is more recognized as fungal pathogen on many economically important plants and on human (Guarro \& Gene 1995, O’Donnell et al. 2009), however, they are also frequently isolated as endophytes from various plants and capable in producing secondary metabolites with medicinal and antimicrobial activities (Kour et al. 2008, Deng et al. 2009, Li et al. 2008, Tayung et al. 2011). Several species belonging to Fusarium oxysporum complex are also known causing human infections in immunocompromised patients (Hennequin et al. 1999). Currently, there are approximately 1132 legitimate names of Fusarium recognized in the Mycobank fungal databases (www.mycobank.org). 
Endophytic Fusarium has been well-known for their activities in inducing plant host resistance to pathogen or enhancing plant fitness to environmental stresses (Bacon \& Yates 2006). Several studies on secondary metabolites discovery also found that many endophytic Fusarium species have been reported to produce metabolites with medicinal properties such as antimicrobial and anticancer activities (Shiono et al. 2007, Shweta et al. 2010, Tayung et al. 2011). Despite their agrochemical and biomedical importance, most of the potential endophytic Fusarium remain unidentified until species level, or phylogenetically uncharacterized.

In the last 10 years, application of phylogenetic species concept in determination of fungal endophyte diversity on various plants, either by using single gene or multigene analyses, becomes more important due to its robustness in revealing many cryptic fungal endophytes species. Traditional identification method of endophyte such as morphological and cultural characterization have been failed to identify many fungal endophytes even up to a familial level (Jeewon et al. 2013). Morphological and cultural approaches in identification of fungal endophyte species are problematic because mycelia pigmentation, shape and size of conidia are unstable and dependent on composition of media and environmental condition (Guo et al. 2001). Identification of Fusarium until species level (saprobes, pathogen or endpohyte) is currently involving combination of morphology species concept and phylogenetic species concept. Additional information from biological species concept such as vegetative compatibility groups (VCGs) and mating type is necessary for lower taxonomy identification such forma speciales (Leslie \& Summerell 2006). Among them, phylogenetic species concept has been known as the most consistent concept for the identification of Fusarium members (Steenkamp et al. 2002). Currently, this approach involving combination of several gene regions such as the internal transcribed spacer (ITS) and the elongation factor $1 \alpha(\mathrm{EF}-1 \alpha)$ regions (O'Donnell et al. 1998), $\beta$-tubulin ( $\beta$-tub) and aminoadipate reductase gene regions (lys2) (Watanabe et al. 2011). Several new cryptic species of endophytic Fusarium were determined using this approach (Walsh et al. 2010).

In this study, six isolates of endophytic Fusarium from Cinchona calisaya Wedd. (common name: quina) [syn. Cinchona ledgeriana (Howard) Bern.Moens ex Trimen] (Rubiaceae), a medicinal plant for malarial fever disease, were characterized for their ability in producing cinchona alkaloids, such as quinine, quinidine, cinchonine, cinchonidine (Maehara et al. 2010). Identity of these isolates was determined using combination of morphology, cultural characteristics, and phylogenetic analysis based on DNA sequence generated from the ITS and the EF-1 $\alpha$ gene regions.

\section{Materials \& Methods}

\section{Collection of samples}

Specimen collection was conducted at quina plantation managed by the Research Center for Tea and Quina, Gambung, West Java, Indonesia in 29 September 2012. The specimen were collected from five individual healthy plants by cutting off asymptomatic flowers, leaves, petioles, stems, barks, and roots of $C$. calisaya. Five pieces of each organ were placed in zipped plastic bags. The plastic bags were sealed and labelled with the name of the host, collection site, date and collector/s. All materials were kept in ice boxes prior to isolation in the laboratory.

\section{Isolation}

The isolation protocol of endophytic fungi referred to the method described by Mostert et al. (2001) with modification. The materials were washed thoroughly in running tap water, and then surface-sterilized using 70\% ethanol $(\mathrm{EtOH})$ for $1 \mathrm{~min}$, followed by soaking in sodium hypochlorite $(\mathrm{NaOCl}) 3 \%$ for $2 \mathrm{~min}$, and $70 \%$ ethanol for $20 \mathrm{~s}$. The samples were rinsed in sterile distilled water three times, and dried with sterile paper for at least $6 \mathrm{~h}$. The sterile distilled water of the final rinse was poured onto the agar medium as a quality control of sterilization process.

After drying, samples were cut into segments approximately $0.5 \times 1 \mathrm{~cm}$ and placed on the surface of Malt Extract Agar (MEA) medium (Difco, USA) (4 segments/petri dishes). All petri dishes were incubated at room temperature. Three replications were made for each sample. Hypal tips 
growing out from the plated plant segments were immediately transferred onto Potato Dextrose Agar (PDA) (Difco, USA) plate. The growth of endophytic fungi mycelium was observed everyday, for about $30 \mathrm{~d}$. The growing colonies were purified using hyphal tip isolation method to get a pure culture. Specimen herbarium was deposited at Hebarium Bogoriense (BO), Cibinong, under accession number BO 1913291. Culture isolates obtained in this study were deposited at the Bogor Agriculture University (IPB) culture collection (IPBCC), Dramaga, under accession number IPBCC.15.1250, IPBCC.15.1253, IPBCC.15.1251, IPBCC.15.1248 and IPBCC.15.1249 (Table 1).

Table 1 Genbank accession number and strain code/culture collection number of Fusarium species used in this study.

\begin{tabular}{|c|c|c|c|}
\hline \multirow{2}{*}{ Species } & \multirow{2}{*}{ Strain } & \multicolumn{2}{|c|}{ GenBank accession number } \\
\hline & & ITS & EF1- $\alpha$ \\
\hline Fusarium solani & IPBCC 15.1248 & LC026135 & LC049293 \\
\hline Fusarium solani & IPBCC.15.1249 & LC026136 & LC049294 \\
\hline Fusarium incarnatum & IPBCC 15.1251 & LC026133 & LC049292 \\
\hline Fusarium incarnatum & IPBCC 15.1252 & LC026134 & LCO49295 \\
\hline Fusarium incarnatum & IPBCC 15.1253 & LC026132 & LC049291 \\
\hline Fusarium oxysporum & IPBCC 15.1250 & LC026138 & LCO49072 \\
\hline Fusarium acuminatum & NRRL 52789 & JF740933 & JF740857 \\
\hline Fusarium asiaticum & MAFF 240264 & AB586991 & AB674269 \\
\hline Fusarium asiaticum & NRRL 26156 & NR 121320 & AF212452 \\
\hline Fusarium avenaceum & MAFF 239206 & AB587016 & AB674293 \\
\hline Fusarium cerealis & NRRL 25491 & AF006340 & AF212465 \\
\hline Fusarium cerealis & MAFF 241212 & AB820717 & AB820701 \\
\hline Fusarium decemcellulare & MAFF 238421 & AB587017 & AB674294 \\
\hline Fusarium decemcellulare & MAFF 238422 & AB587018 & AB674295 \\
\hline Fusarium dimerum & CBS 63276 & AB586995 & AB674273 \\
\hline Fusarium dimerum & MAFF 237465 & AB586996 & AB674274 \\
\hline Fusarium equiseti & NRRL 26419 & GQ505688 & GQ505599 \\
\hline Fusarium equiseti & MAFF 236434 & AB586999 & $\mathrm{AB} 674277$ \\
\hline Fusarium equiseti & MAFF 236723 & AB587000 & AB674278 \\
\hline Fusarium incarnatum & MAFF 236521 & AB586988 & KF255493 \\
\hline Fusarium graminearum & MAFF 240270 & AB586992 & AB674270 \\
\hline Fusarium kyushuense & MAFF 237645 & AB587019 & AB674296 \\
\hline Fusarium kyushuense & NRRL 6490 & FSU85545 & AB674297 \\
\hline Fusarium larvarum & CBS 16930 & AB586984 & AB674265 \\
\hline Fusarium larvarum & CBS 63876 & AB586985 & AB674266 \\
\hline Fusarium langsethiae & CBS 113234 & AB587021 & AB674298 \\
\hline Fusarium langsethiae & FRC T 1000 & AB587023 & AB674300 \\
\hline Fusarium lateritium & MAFF 235344 & AB587004 & AB674281 \\
\hline Fusarium merismoides & MAFF 236504 & AB586998 & AB674276 \\
\hline Fusarium oxysporum & CBS 133023 & KF255448 & KF255492 \\
\hline Fusarium oxysporum & CBS 12773 & KF913730 & KF913725 \\
\hline Fusarium poae & FRC T 0796 & AB586983 & AB674301 \\
\hline Fusarium poae & MAFF 305947 & AB587024 & AB674302 \\
\hline Fusarium phyllophilum & CBS 21676 & AB587006 & AB674283 \\
\hline Fusarium solani & CBS 132898 & KF255440 & KF255484 \\
\hline Fusarium solani & NRRL 28579 & DQ094383 & DQ246910 \\
\hline Fusarium solani & MAFF 238538 & AB587013 & AB674290 \\
\hline Fusarium subglutinans & ATCC 38016 & AB587008 & AB674285 \\
\hline Fusarium sporotrichioides & CBS 119839 & AB587026 & AB674304 \\
\hline Fusarium sporotrichioides & MAFF 236639 & AB587027 & AB674305 \\
\hline Fusarium sporotrichioides & ATCC 34914 & AB587025 & AB674303 \\
\hline Fusarium tricinctum & ATCC 38183 & AB587028 & AB674264 \\
\hline Fusarium tricinctum & CBS 39393 & AB587029 & AB674263 \\
\hline Fusarium tricinctum & MAFF 235551 & AB587030 & AB674262 \\
\hline Fusarium verticillioides & CBS 57678 & AB587010 & AB674287 \\
\hline Fusarium verticillioides & MAFF 240085 & AB587012 & AB674289 \\
\hline Penicillium citrinum & AX4602 & KJ413363 & KJ476397 \\
\hline
\end{tabular}




\section{Morphological and cultural characterization}

Morphological-based determination of Fusarium referred to the identification key described by Leslie \& Summerell (2006). Colony characterization of each isolate was conducted to the 7 days old isolates growth on the PDA medium. The colony characteristics observed include diameter, color of the surface and reverse, margin, and texture. Microscopic structures, such as macroconidia, microconidia, conidiogenous cells and chlamydospore were examined by using Olympus BX53 light microscope (OLYMPUS, Japan) under 1000× magnification using immersion oil. Shear's solution was used as mounting medium (Kirk et al. 2008). Thirty measurements were taken to all microscopic characters.

\section{Molecular characterization}

\section{DNA isolation, PCR amplification and sequencing}

Genomic DNA from $7 \mathrm{~d}$ fungal mycelia growth in $5 \mathrm{~mL}$ of Potato Dextrose Broth (PDB) (Difco, USA) were harvested using Phytopure ${ }^{\mathrm{TM}}$ DNA extraction kit (GE Healthcare, UK) following the manufacturer's protocol. Amplification of genomic DNA was done using Polymerase Chain Reaction (PCR) method performed in a $25 \mathrm{~mL}$ reaction volume as follow: $10 \mu \mathrm{L}$ nuclease free water, $12.5 \mu \mathrm{L}$ DreamTaq ${ }^{\circledR}$ green master mix (Thermo scientific, USA), $0.5 \mu \mathrm{L}$ of forward and reverse primer, $0.5 \mu \mathrm{L}$ DMSO and $1 \mu \mathrm{L}$ DNA template. The primer pairs of ITS5 (forward) (5'TCCTCCGCTTATTGATATGC-3') and ITS4 (reverse) (5'-TCCGTAGGTGAACCTGCGC-3') (White et al. 1990) were used to amplify the ITS region including 5.8S rDNA. The PCR condition for the ITS region was set as follow: $90 \mathrm{~s}$ at $95^{\circ} \mathrm{C}$ for initial denaturation, followed by 35 cycles of $30 \mathrm{~s}$ at $95^{\circ} \mathrm{C}$ denaturation, $30 \mathrm{~s}$ at $55^{\circ} \mathrm{C}$ annealing, $90 \mathrm{~s}$ at $72^{\circ} \mathrm{C}$ extension and $5 \mathrm{~min}$ at $72^{\circ} \mathrm{C}$ for the final extension. For the amplification of partial translation EF-1 $\alpha$, the primer pairs of EF1-728F $\left(5^{\prime}-\right.$ CATCGAGAAGTTCGAGAAGG-3') and EF1-986R (5'-TACTTGAAGGAACCCTTACC-3') (Carbone \& Kohn 1999) were employed. PCR reaction was performed in $25 \mathrm{~mL}$ as follow: nuclease free water $8.75 \mu \mathrm{L}$, Gotaq ${ }^{\circledR}$ green master mix (Promega, USA) $12.5 \mu \mathrm{L}, 0.625 \mu \mathrm{L}$ for each forward and reverse primer, DMSO $0.5 \mu \mathrm{L}$ and DNA templete $2 \mu \mathrm{L}$. The PCR condition was set as follows: $94^{\circ} \mathrm{C}$ for $5 \mathrm{~min}$ for initial denaturation, followed by 35 cycles of $30 \mathrm{~s}$ at $94^{\circ} \mathrm{C}$ denaturation, $30 \mathrm{~s}$ at $52^{\circ} \mathrm{C}$ annealing, $30 \mathrm{~s}$ at $72^{\circ} \mathrm{C}$ extension and $7 \mathrm{~min}$ at $72^{\circ} \mathrm{C}$ for final extension. All PCR reactions were performed using T100 thermal cycler (Bio-Rad, USA). PCR products were electrophorized in a $1 \%$ (w/v) agarose gel soaked in $1 \times$ TAE buffer at $100 \mathrm{~V}$ for $30 \mathrm{~min} .1 \mathrm{~kb}$ DNA ladder was used as a marker during the electrophoresis. The gel was soaked in EtBr (ethidium bromide) for 30 min prior to UV light examination using Gel Doc XR system (Bio-Rad, USA). Purified PCR products were sent to 1stBASE (Malaysia) for sequencing.

\section{Phylogenetic analysis}

Nucleotide sequences obtained from the respective primer pairs (ITS5 and ITS4, EF1-728F and EF1-986R) were examined and refined by direct examination using Chromas Pro 1.41 software (Technelysium Pty Ltd., Australia). Newly ITS and EF 1- $\alpha$ sequences of endophytic Fusarium from $C$. calisaya were aligned with DNA sequence from 43 Fusarium isolates of Watanabe et al. (2011) using MUSCLE (Edgar 2004) implemented in MEGA 6 (Tamura et al. 2013). Penicillium chrysogenum strain CBS 906.70 was used as outgroup in the analyses. Regions designated as ambiguously aligned were excluded from the analyses. GeneBank accession number, strain code and taxon names used in this study are showed in Table 1.

Phylogenetic analysis was conducted using the maximum parsimony (MP) method in PAUP* $4.0 \mathrm{~b} 10$ (Swofford 2002). The heuristic search option using the 'tree-bisection-reconstruction' (TBR) algorithm with 1000 random sequence additions was performed to find the optimum tree. The stepwise addition option set as random and maximum tree number was set at 500. Tree length (TL), consistency index (CI), retention index (RI), related consistency index (RC), and homoplasy index (HI) were also calculated. The strength of the internal branches of the phylogenetic tree in MP analysis was tested with bootstrap (BS) analysis (Felsenstein 1985) using 1000 replications. BS values of $50 \%$ or higher 
than that are shown. Random sequence addition was used in the bootstrap analysis. All sites were treated as unordered and unweighted, and gaps treated as missing data. The partition homogeneity test (Farris et al. 1995) with 1000 replicates, 10 random addition sequence replicates, and TBR branch swapping was conducted by using PAUP* to determine whether ITS and EF-1 $\alpha$ datasets were in conflict. A significance level of $\mathrm{P}=0.01$ was adopted for this test (Cunningham 1997). TreeGraph 2 software (Stöver \& Müller 2010) was used to refine the phylogenetic tree.

\section{Cinchona alkaloids analyses}

Determination of cinchona alkaloids was qualitatively and quantitatively carried out according to the method described by Simanjuntak et al. (2002). Each Fusarium isolate was inoculated into 200 $\mathrm{mL}$ PDB medium $\mathrm{pH} \pm 6.0$ in $500 \mathrm{~mL}$ Erlenmeyer flasks. The cultures were incubated with static methods for $21 \mathrm{~d}$ at room temperature. After $21 \mathrm{~d}$, biomass and filtrate of fungal isolates from the fermentation flasks were homogenized and extracted with the addition of chloroform p.a. $\left(\mathrm{CHCl}_{3}\right.$, $\geq 99.8 \%$ ) as a solvent solution. This step was carried out three times for each sample. Each fraction was collected and concentrated by rotary evaporator at a temperature of $45^{\circ} \mathrm{C}$ and $60 \mathrm{rpm}$ rotation. The extracts of the endophytic fungus were analyzed quantitatively by high performance liquid chromatography (HPLC) types Perkin Elmer Series $200 \mathrm{UV}-\mathrm{Vis}$ detector, nonpolar ascentis ${ }^{\circledR} \mathrm{C} 18$ HPLC column, $5 \mu \mathrm{m}, \mathrm{L} \times$ I.D. $25 \mathrm{~cm} \times 4.6 \mathrm{~mm}$, eluent $\mathrm{KH}_{2} \mathrm{PO}_{4} 20 \mathrm{mM}$ pH 2.5: $\mathrm{CH}_{3} \mathrm{CN}=75 \%: 25 \%$, and a flow rate at $1.20 \mathrm{~mL} /$ minute. HPLC condition was set as follow: column Cosmosil 5C18-MS-II $(4.6 \times 150 \mathrm{~mm})$, mobile phase using Methanol : Acetonitril $(80: 20)$, flow rate at $1.0 \mathrm{~mL} / \mathrm{min}$, column temperature at $40^{\circ} \mathrm{C}$ and detection wavelength at $210 \mathrm{~nm}$. The concentration of cinchona alkaloids were calculated as follows:

Concentration $\left(\mathrm{mg} . \mathrm{L}^{-1}\right)=($ Sample Area $\times$ Concentration of Standard $):$ Standard Area

To affirm the HPLC results, analysis of absorption spectra were carried out by using UV-Vis spectrophotometer (Germany). Absorption spectra of metabolites present in the extract were determined by making the absorption scan in range from $190 \mathrm{~nm}$ to $400 \mathrm{~nm}$.

\section{Results}

\section{Morphological and cultural characterization}

The morphology and cultural characteristics of six Fusarium isolates from C. calisaya on PDA medium after $7 \mathrm{~d}$ incubation were described in Table 2. The colony caharacteristics of Fusarium isolates strain IPBCC 15.1251 and IPBCC 15.1253 were slightly different to those of strain IPBCC 15.1248, strain IPBCC 15.1249 and strain IPBCC 15.1250 due to producing pink to light red pigmentation on the PDA medium, and microcospically having aseptate macroconidia after $7 \mathrm{~d}$ incubation. In addition, Fusarium isolate strain IPBCC 15.1250 producing purple to dark purple pigmentation on the medium, while strain IPBCC 15.1248 and strain IPBCC 15.1249 did not produce any pigmentations.

\section{Phylogenetic analysis}

The partition homogeneity test of the two datasets-ITS and part of EF-1 $\alpha$ regions-showed that significant conflict exist between the phylogenies of the individiual dataset $(\mathrm{P}<0.01)$. Therefore, we constructed the datasets separately as individual phylogenetic analysis. In the parsimony analysis of ITS sequence dataset, the alignment contained 49 sequences and 489 total characters, of which 257 characters are constant, 60 characters are variable and parsimony-uninformative, 172 characters are parsimony-informative. All characters have equal weight. The best parsimonious tree was generated in 555 steps $(\mathrm{CI}=0.647, \mathrm{RI}=0.862, \mathrm{RC}=0.558, \mathrm{HI}=0.353)$. The endophytic Fusarium sequences from C. calisaya were divided into three distinct lineages (Fig. 1). Sequence of Fusarium sp. strain IPBCC 15.1251, IPBCC 15.1252 and IPBCC 15.1253 nested in the clade containing $F$. equiseti-F. incarnatum complex ( $F$. equiseti strain MAFF 236434, strain MAFF 236723, strain NRRL 26419T and $F$. incarnatum strain MAFF 236521) with 99\% BS, sequence of strain IPBCC 15.1250 forming monophyletic clade with members of $F$. oxysporum $(F$. oxysporum strain CBS 127.73 and strain CBS 
133023T) (BS $=90 \%)$, and sequence of strain IPBCC 15.1248 and IPBCC.15.1249 nested in the clade containing $F$. solani sequences $(F$. solani strain CBS 132898, strain NRRL 28579T and $F$. solani $\mathrm{f}$. mori strain MAFF 238538) with $100 \%$ BS.

The alignment of partial EF-1 $\alpha$ composed of 49 sequences and 345 total characters, of which 72 characters are constant, 61 characters are variable and parsimony-uninformative, 212 characters are parsimony-informative. All characters have equal weight. The best parsimonious tree was generated in 892 steps $(\mathrm{CI}=0.565, \mathrm{RI}=0.792, \mathrm{RC}=0.448, \mathrm{HI}=0.435)$. The placement of six endophytic Fusarium sequences in the phylogenetic tree generated from partial $\mathrm{EF}-1 \alpha$ dataset is similar to that of the ITS tree (Fig. 2). Sequence of Fusarium sp. strain IPBCC 15.1251, IPBCC 15.1252 and IPBCC 15.1253 nested in the clade containing $F$. equiseti-F. incarnatum complex with $95 \% \mathrm{BS}$, sequence of strain IPBCC 15.1250 forming monophyletic clade with $F$. oxysporum clade $(\mathrm{BS}=99 \%)$, and sequence of strain strain IPBCC 15.1248 and IPBCC.15.1249 nested in the $F$. solani clade with $97 \%$ BS. Based on the phylogenetic trees (ITS and partial EF-1 $\alpha$ ) analyses, the sequence of Fusarium strain IPBCC 15.1250 was determined as $F$. oxysporum, and the Fusarium sequence strain IPBCC 15.1248 and IPBCC.15.1249 were determined as $F$. solani. However, these datasets were failed to resolve the species name of Fusarium spp. strain IPBCC 15.1251, IPBCC 15.1252 and IPBCC 15.1253.

In order to resolve the identity of the Fusarium spp. strain IPBCC 15.1251, IPBCC 15.1252 and IPBCC 15.1253, we conducted separate phylogenetic analysis based on partial EF-1 $\alpha$ sequence involving these three sequences with 42 sequences belonging to $F$. equiseti-incarnatum complex used by Castellá and Cabañes (2014). Sequence of $F$. asiaticum strain NRRL 26156 (GenBank accession number: AF212452) was used as outgroup. All genbank accession number, strain code and taxon names used in this analysis were showed in Fig. 3. The alignment of this dataset composed of 46 sequences and 255 total characters included in the analysis, of which 144 characters were constant, 43 characters were variable and parsimony-uninformative, 68 characters were parsimony-informative. All characters have equal weight. The best parsimonious tree was generated in 204 steps $(\mathrm{CI}=0.667$, $\mathrm{RI}=0.851, \mathrm{RC}=0.567, \mathrm{HI}=0.333$ ). The phylogenetic tree showed that sequence of Fusarium spp. strain IPBCC 15.1251, IPBCC 15.1252 and IPBCC 15.1253 formed monophyletic clade with $F$. incarnatum NRRL 34004 (GQ505628) (BS = $71 \%$ ). This clade nested within the large monophyletic clade containing sequences belong to $F$. incarnatum sensu stricto (s.str.) (BS $=83 \%$ ). Based on this analysis, Fusarium spp. strain IPBCC 15.1251, IPBCC 15.1252 and IPBCC 15.1253 were determined as $F$. incarnatum.

\section{Cinchona alkaloids analyses}

The HPLC analysis showed that four strains were capable in producing quinine, viz, $F$. incarnatum strain IPBCC 15.1253 and strain IPBCC $15.1251 ; F$. oxysporum strain IPBCC 15.1250; and $F$. solani strain IPBCC 15.1248 and strain IPBCC.15.1249. It was demonstrated by having similar retention time $(\mathrm{Rt})$ with the quinine standard ( $\pm 2.2 \mathrm{~min}$ ) (Fig. 4). The concentration of quinine produced by the Fusarium isolates in this study range from 0.7 to $0.9 \mathrm{mg} / \mathrm{L}$, while cinchonidine range from $2.5 \times 10^{-5}$ to $1.0 \times 10^{-4} \mathrm{mg} / \mathrm{L}$ after $21 \mathrm{~d}$ incubation (Table 3 ).

Among them, $F$. incarnatum strain IPBCC 15.1253 and strain IPBCC $15.1251 ; F$. oxysporum strain IPBCC 15.1250; and $F$. solani strain IPBCC.15.1249 were also capable in producing cinchonidine in synthetic medium. It was shown by having small peak at 1.9 min retention time similar to cinchonidine standard (Fig. 4). Because the peak in HPLC analysis was not really clear, we carried out UV-Vis spectroscopy analysis to affirm the HPLC results. UV-Vis spectra showed close retention time between the peaks of quinine and cinchonidine standards at $\pm 239 \mathrm{~nm}$ and $\pm 280 \mathrm{~nm}$, respectively (Fig. 5a). This figure also showed that the cinchonidine spectrum was weaker than quinine in absorbing UV. Based on the UV-Vis analysis, quinine and cinchonidine were detected from the extracts of $F$. incarnatum strain IPBCC 15.1253 and strain IPBCC $15.1251 ; F$. oxysporum strain IPBCC 15.1250; and F. solani strain IPBCC.15.1249, but cinchonidine peak was in low resolution (Figs. 5b-f). This is probably due to low concentration of cinchonidine in the fungal extracts, particularly in the extracts of $F$. oxysporum strain IPBCC 15.1250 (Fig. 5b) and $F$. solani strain IPBCC 15.1249 (Fig. 5e). 
Table 2 Morphological and cultural characteristics of endophytic Fusarium from C. calisaya on PDA after 7 d incubation.

\begin{tabular}{|c|c|c|c|c|c|}
\hline Character & $\begin{array}{l}\text { F. incarnatum strain } \\
\text { IPBCC.15.1253 }\end{array}$ & $\begin{array}{l}\text { F. incarnatum } \text { strain } \\
\text { IPBCC.15.1251 }\end{array}$ & $\begin{array}{lrr}F . & \text { oxysporum } & \text { strain } \\
\text { IPBCC.15.1250 } & \end{array}$ & $\begin{array}{l}\text { F. solani strain } \\
\text { IPBCC.15.1248 }\end{array}$ & $\begin{array}{lc}F . & \text { solani } \\
\text { IPBCC.15.1249 }\end{array}$ \\
\hline Colony & cottony, aerial & cottony, aerial & cottony, immersed & cottony, aerial & cottony, immersed \\
\hline Diameter of colony $(\mathbf{c m})$ & 4.2 & 4.8 & 4.3 & 5.8 & 4.8 \\
\hline Conidiophore & long and single & long and single & short & long and single & long and single \\
\hline Conidiogenous cell $(\mu \mathrm{m})$ & $\begin{array}{l}\text { monophialide, } 1.5 \times \\
4.5\end{array}$ & monophialide, $1.4 \times 4.3$ & monophialide, $1.9 \times 6.7$ & $\begin{array}{l}\text { monophialide, } 3.3 \times \\
5.9\end{array}$ & monophialide, $2.7 \times 9.3$ \\
\hline Microconidia $(\mu \mathrm{m})$ & $\begin{array}{l}\text { oblong to ovoid, } \\
\text { aseptate, } 2.9-3.9 \times \\
6.1-8.6\end{array}$ & $\begin{array}{l}\text { oblong to ovoid, aseptate, } \\
8.7-11 \times 15.4-25.7\end{array}$ & $\begin{array}{l}\text { oval to elliptical, aseptate, } \\
8.8-12.9 \times 25.4-34.6\end{array}$ & $\begin{array}{l}\text { oval, aseptate, } 2.9-5.2 \\
\times 13.2-17.2\end{array}$ & $\begin{array}{l}\text { oval, aseptate, } 2.9-8.7 \times \\
8.9-20.9\end{array}$ \\
\hline Macroconidia $(\mu \mathrm{m})$ & $\begin{array}{l}\text { oblong to elliptical, } \\
\text { aseptate, } 3.6-4.2 \times \\
11.9-20.9\end{array}$ & $\begin{array}{l}\text { oblong to elliptical, } \\
\text { aseptate, } 3.5-11 \times \\
13.7-45.3\end{array}$ & $\begin{array}{l}\text { obovate, } 3-6 \quad \text { septate, } \\
8.5-11.8 \times 31.9-70.4\end{array}$ & $\begin{array}{l}\text { obovate, septate }(4-6) \text {, } \\
19.9-38.6 \times 3.4-5.9\end{array}$ & $\begin{array}{l}\text { obovate, septate, } 3.4-11.4 \\
\times 19.9-62.6\end{array}$ \\
\hline Chlamydospore $(\mu \mathrm{m})$ & $\begin{array}{l}\text { present, } \quad \text { obovoid, } \\
\text { intercalar, } 6.3 \times 8.5\end{array}$ & $\begin{array}{l}\text { present, } \quad \text { globular, } \\
\text { intercalar and terminal, } \\
5.3-7.9 \times 7.1-9.7\end{array}$ & $\begin{array}{l}\text { present, globular, } \\
\text { intercalar, terminal, } 6.1- \\
10.6 \times 5.4-11.4\end{array}$ & $\begin{array}{l}\text { present, } \quad \text { oval, } \\
\text { intercalar, } \\
7.5-6.5 \times \\
7.3-8.1\end{array}$ & $\begin{array}{l}\text { present in chain or single, } \\
\text { oval, intercalar, } 4.6-8.8 \times \\
6.5-9.2\end{array}$ \\
\hline Color & white to pink & white to pink & purple/dark purple & white to pale & white to pale \\
\hline Source & Petiole & fruit & bark & Twig & twig \\
\hline
\end{tabular}




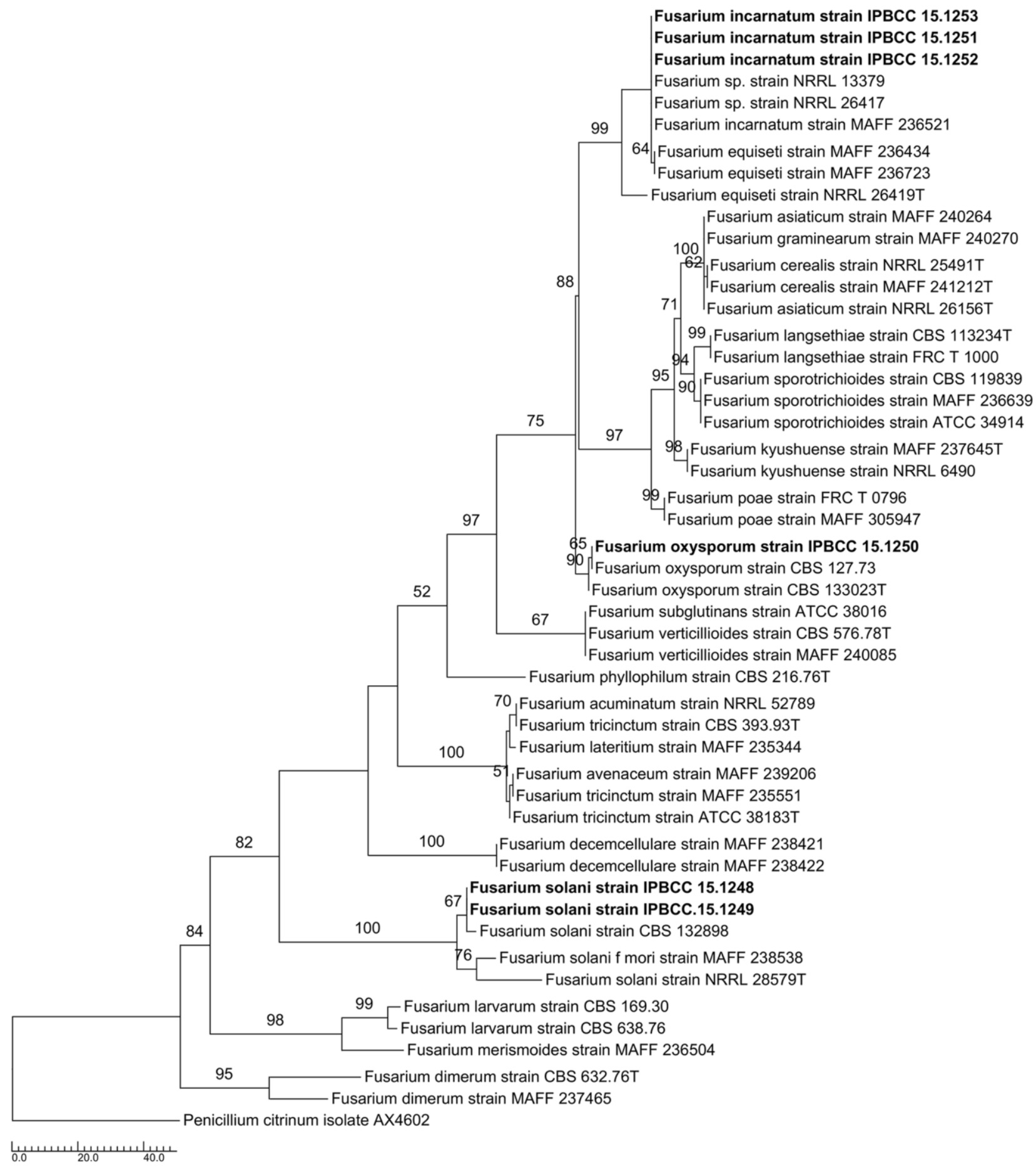

Fig. 1 - Maximum Parsimony (MP) tree showing relationship between endophytic Fusarium spp. from C. calisaya with related species based on the ITS rDNA sequences. Bootstrap value $>50 \%$ is shown at the branches node.

\section{Discussion}

It was predicted by several researchers that each of about 300,000 species of plants in terrestrial ecosystem is likely associated with more than one species of bacterial and fungal endophytes (Strobel \& Daisy 2003). With their capability in producing various bioactive compounds, fungal endophytes has gained more attention in discovery of new secondary metabolites, or as an alternative source to replace plants as bioactive plant secondary metabolites producer due to their ability to synthesize similar or the same natural products produced by the plants (Kusari \& Spiteller 2011). Despite this 


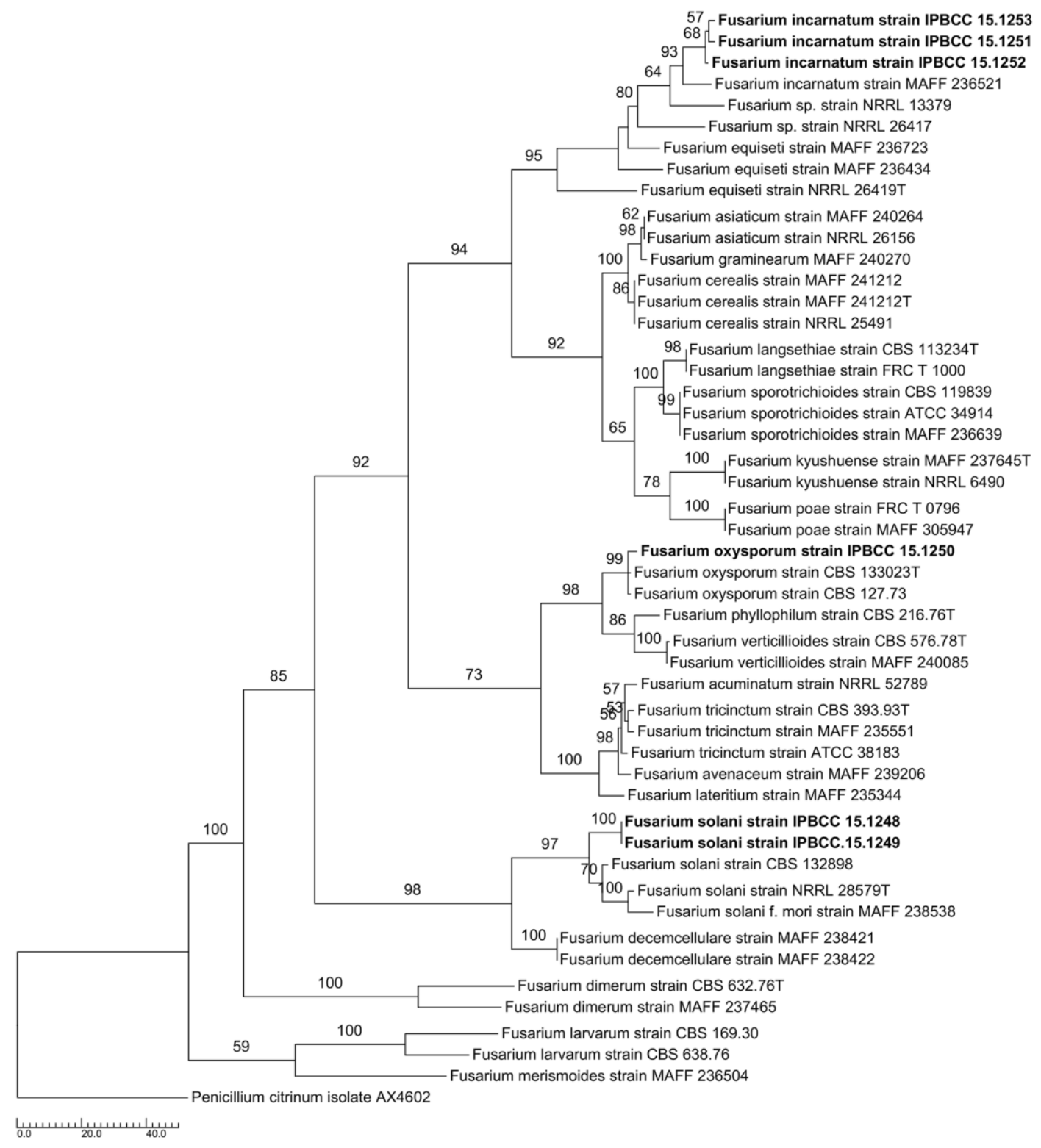

Fig. 2 - Maximum Parsimony (MP) tree showing relationship between endophytic Fusarium spp. from C. calisaya with related species based on the EF-1 $\alpha$ sequences. Bootstrap value $>50 \%$ is shown at the branches node.

potential, majority of the potential endophytic fungi remain taxonomically uncharacterized (Huang et al. 2009). Therefore, efforts on discovery of new secondary metabolites from fungal endophytes must be carried out in line with the fungal endophytes taxonomical study to reveal their true scientific name identity.

Quinine is widely recognized as one of Cinchona alkaloids produced as secondary metabolites from the bark of Cinchona plants (Cinchona spp.). Since its finding in 1820, quinine has been used as the main medication for malaria disease due to its effectivity against erythrocytic stage of the parasite Plasmodium falciparum (Wijnsma \& Verpoorte 1988). One of the earlier report indicating Cinchona alkaloids production by fungal endophytes was published by Simanjuntak et al. (2002). In further report, taxonomical identity of common fungal endophyte capable of producing quinine was determined belonging to the genus Diaporthe (anamorph: Phomopsis) (Maehara et al. 2012). Different genera of endophytic fungi such as Arthrinium, Fomitopsis, Penicillium, Schizophyllym and Xylaria were also reported as potential quinine producer (Shibuya et al. 2003, Agusta et al. 2005, Maehara et al. 2010). 




Fig. 3 - Maximum Parsimony (MP) tree showing phylogenetic affinities of Fusarium isolates strain IPBCC 15.251, IPBCC 15.252 and IPBCC 15.253 within Fusarium incarnatum-equiseti complex. Bootstrap value $>50 \%$ is shown at the branches node. 
Table 3 HPLC analysis of Cinchona alkaloids from endophytic Fusarium spp.

\begin{tabular}{|c|c|c|c|c|c|c|}
\hline & \multicolumn{4}{|c|}{ Alkaloids } \\
\hline & & & Quinine & Quinidine & Cinchonine & Cinchonidine \\
\hline \multicolumn{3}{|c|}{ Retention time (Rt) standard } & 2.2 & 2.6 & 1.7 & 1.9 \\
\hline \multirow[t]{4}{*}{ F. incarnatum } & IPBCC 15.1251 & Area & 41398776 & - & - & 1701 \\
\hline & & Concentration (mg/L) & 0.8 & - & - & $3.6 \times 10^{-5}$ \\
\hline & IPBCC 15.1253 & Area & 47547190 & - & - & 5125 \\
\hline & & Concentration (mg/L) & 0.9 & - & - & $1 \times 10^{-4}$ \\
\hline \multirow[t]{2}{*}{ F. oxysporum } & IPBCC 15.1250 & Area & 46398275 & - & - & 1172 \\
\hline & & Concentration $(\mathrm{mg} / \mathrm{L})$ & 0.9 & - & - & $2.4 \times 10^{-4}$ \\
\hline \multirow[t]{4}{*}{ F. solani } & IPBCC 15.1248 & Area & 45494218 & - & - & - \\
\hline & & Concentration $(\mathrm{mg} / \mathrm{L})$ & 0.9 & - & - & - \\
\hline & IPBCC 15.1249 & Area & 34190841 & - & - & 1181 \\
\hline & & Concentration (mg/L) & 0.7 & - & - & $2.5 \times 10^{-5}$ \\
\hline
\end{tabular}
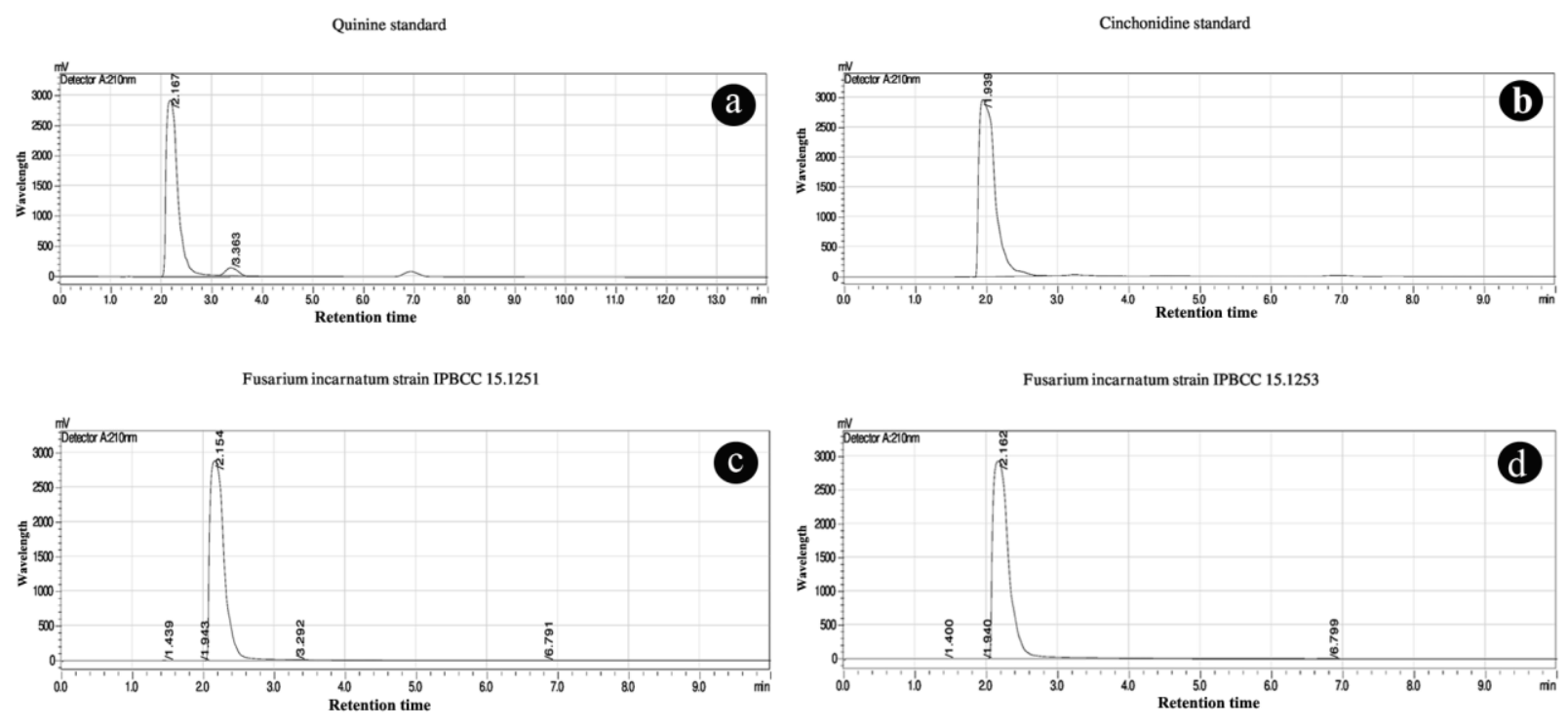

Fusarium solani strain IPBCC 15.1248

Fusarium solani strain IPBCC.15.1249
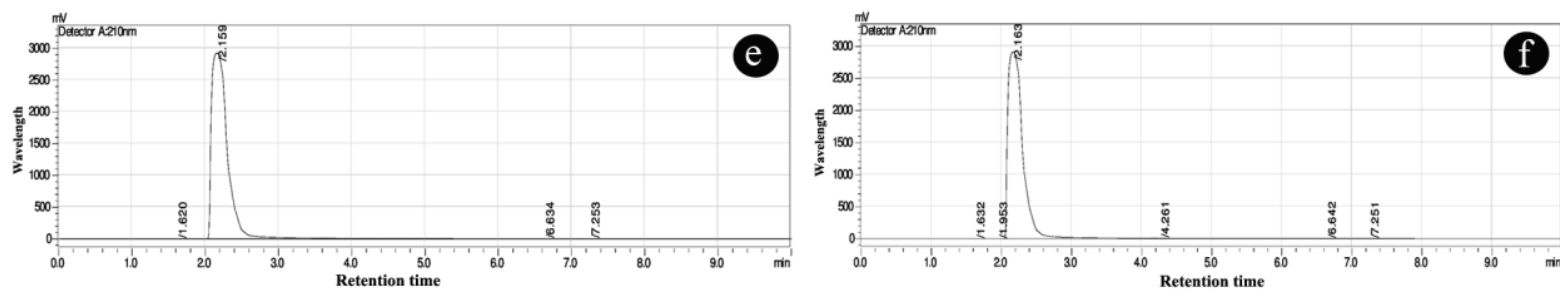

Fusarium oxysporum strain IPBCC 15.1250



Fig. 4a-g - HPLC profiles of Fusarium isolates in this study: a quinine standard. b cinchonidine standard. c $F$. incarnatum strain IPBCC 15.1251. d $F$. incarnatum strain IPBCC 15.1253 . e $F$. solani strain IPBCC 15.1248. f $F$. solani strain IPBCC 15.1249. g F. oxysporum strain IPBCC 15.1250. 

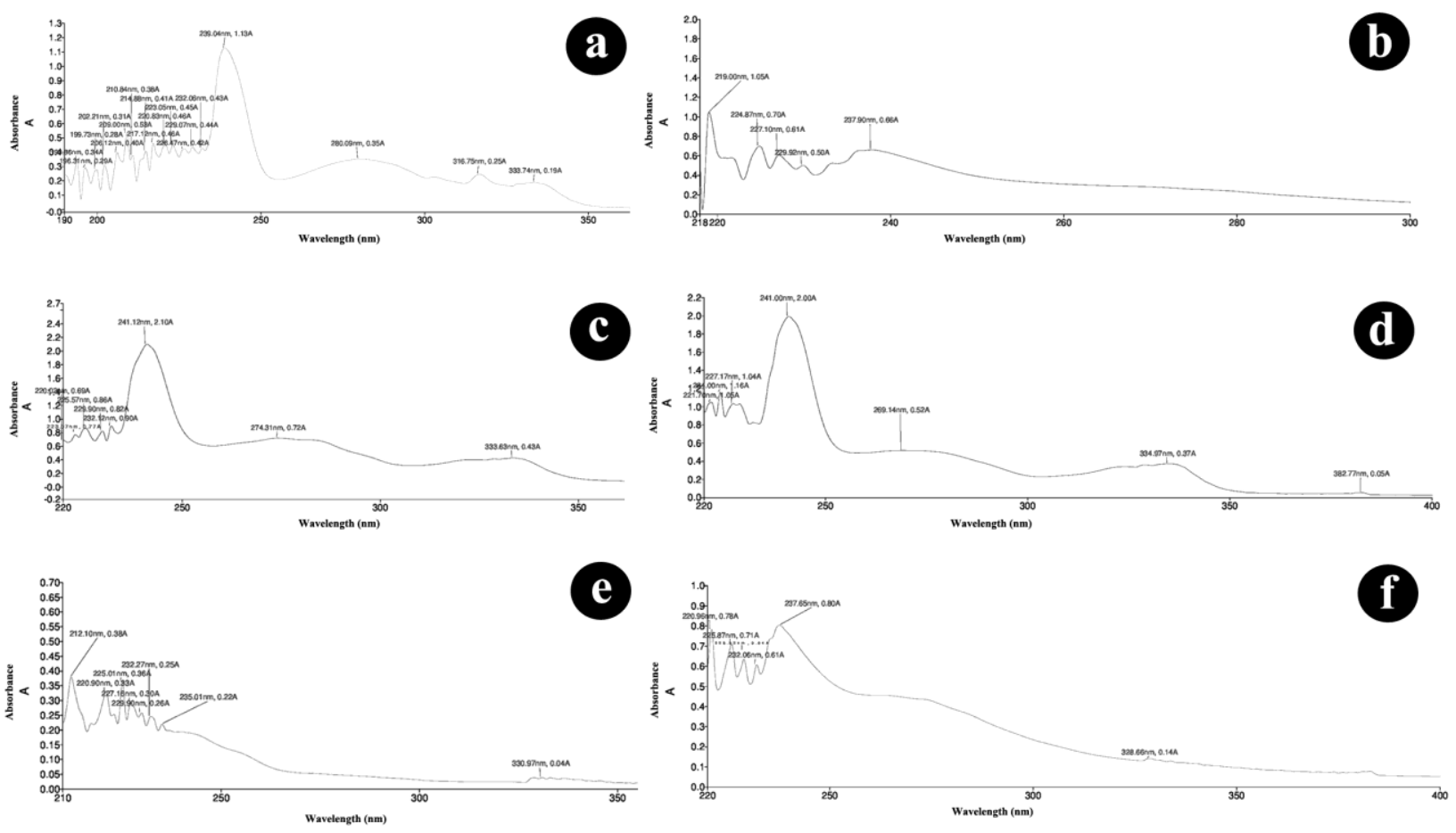

Fig. 5a-f - UV-Vis profiles of Fusarium isolates in this study: a quinine and cinchonidine mixed standard. b $F$. oxysporum strain IPBCC 15.1250. c $F$. incarnatum strain IPBCC 15.1251. d $F$. incarnatum strain IPBCC 15.1253. e $F$. solani strain IPBCC 15.1249. f $F$. solani strain IPBCC 15.1248.

In this study, three Fusarium species are reported as the new fungal endophytes capable of producing quinine, namely, $F$. incarnatum strain IPBCC 15.1253 and strain IPBCC 15.1251, $F$. oxysporum strain IPBCC 15.1250, and $F$. solani strain IPBCC 15.1248 and strain IPBCC.15.1249. These Fusarium isolates, except $F$. solani strain IPBCC 15.1248 , were also capable in producing cinchonidine. All of these Fusarium species were isolated from different types of plant tissue. Fusarium incarnatum strain IPBCC 15.1251 was originally isolated from fruit, while $F$. incarnatum strain IPBCC 15.1253 was isolated from petiole, $F$. oxysporum strain IPBCC 15.1250 from bark, and F. solani strain IPBCC.15.1249 from twig (Table 2). This result not only showed that Fusarium endophytes from quina capable in producing similar Cinchona alkaloids produced by their host, but also revealed that the Cinchona alkaloids can be produced by fungal endophytes such as Fusarium spp. from different plant organs. The concentrations of quinine produced by Fusarium spp. from the current study were also higher than fungal endophytes from the previous studies, such as Diaporthe sp. CLF-J (AB505415), Diaporthe sp. CLF-M (AB505418) and Arthrinium sp. (AB505426) (Maehara et al. 2012, 2013). According to Maehara et al. (2013), endophytic fungi from Cinchona were capable in producing principal Cinchona alkaloids such as quinine, quinidine and cinchonine at concentration $>50$ $\mu \mathrm{g} / \mathrm{L}$. Since the highest quinine contents reside in the Cinchona bark (Song et al. 2009), it is unexpected that non-bark Fusarium endophyte was also produced quinine as high as the Fusarium endophyte isolated from bark.

Phylogenetic analysis of quinine-producing Fusarium species showed that there are more than one species of the genus Fusarium exist as endophyte within plant tissues of $C$. calisaya. The finding of more than one species from a single fungal genus occupied the same species of host plant, in fact, was not uncommon as several authors had previously reported (Niekerk et al. 2005, Santos \& Phillips 2009, Santos et al. 2011, Thompson et al. 2011). The current study also found that a single species of endophyte can occupies different type of plant organs as showed by several morphotypes of $F$. incarnatum isolated from petiole (strain IPBCC.15.1253), fruit (strain IPBCC.15.1251) and bark (strain 
IPBCC.15.1252). Eventually, enormous potential of fungal endophyte diversity as source of secondary metabolites discovery is demonstrated in this study.

\section{Acknowledgements}

This work was financially supported by SATREPS project between NITE (Japan) and LIPI (Indonesia). Bogor agricultural university culture collection (IPBCC) is acknowledged for providing space and equipment during several parts of the laboratory works. The Research Center for Tea and Quina, Gambung (West Java province, Indonesia) is also thanked for specimen collection.

\section{References}

Agusta A, Maehara S, Ohashi K, Simanjuntak P, Shibuya H. 2005 - Stereoselective oxidation at C-4 of flavans by the endophytic fungus Diaporthe sp. isolated from a tea plant. Chem Pharm Bull 53, 1565-1569.

Bacon CW, Yates IE. 2006 - Endophytic Root Colonization by Fusarium Species: Histology, Plant Interactions, and Toxicity. pp. 133-152, in Schulz B, Boyle C, Sieber T (eds.). Microbial root endophytes, Springer-Verlag Berlin Heidelberg.

Carbone I, Kohn LM. 1999 - A method for designing primer sets for speciation studies in filamentous ascomycetes. Mycologia 91, 553-556.

Castellá G, Cabañes FJ. 2014 - Phylogenetic diversity of Fusarium incarnatum-equiseti species complex isolated from Spanish wheat. Antonie van Leeuwenhoek 106, 309-317. doi:10.1007/s10482-014-0200-x.

Cunningham CW. 1997- Can three incongruence tests predict when data should be combined?. Mol Biol Evol 14, 733-740.

Deng BV, Liu KH, Chen WQ, Ding XW, Xie XC. 2009 - Fusarium solani, Tax-3, a new endophytic taxol-producing fungus from Taxus chinensis. World J Microb Biot 25, 139-143. doi:10.1007/s11274-008-987-2.

Dita MA, Waalwijk C, Buddenhagen IW, Souza Jr. MT, Kemab GHJ. 2010 - A molecular diagnostic for tropical race 4 of the banana fusarium wilt pathogen. Plant Phatology 59, 348-357. doi:1111/j.1365-3059.2009.02221.x.

Edgar RC. 2004 - Muscle: multiple sequence alligment with high accurancy and high throughput. Nucleic acids Res 32, 1792-1797. doi:10.1093/nar/gkh340.

Farris JS, Kalllersjo M, Kluge AG, Bult C. 1994 - Testing significance of incongruence. Cladistics 10, 315-319. doi:10.1006/clad.1994.1021.

Felsenstein J. 1985 - Confidence limits on phylogenetic: an approach using the bootstrap. Evolution 39, 783-791.

Guarro J, Gene J. 1995 - Opportunistic Fusarial infections in humans. Eur J Clin Microbiol Infect Dis $14,741-754$.

Guo LD, Hyde KD, Liew ECY. 2001 - Detection and Taxonomic Placement of Endophytic Fungi within Frond Tissues of Livistona chinensis Based on rDNA Sequences. Molecular Phylogenet Evol 20, 1-13.

Hennequin C, Abachin E, Symoens F, Lavarde V, Reboux G, Nolard N, Berche P. 1999 Identification of Fusarium species involved in human infections by $28 \mathrm{~S}$ rRNA gene sequencing. J Clin Microbiol 37, 3586-3589. doi:0095-1137/99/804.00.

Huang WY, Cai YZ, Surveswaran S, Hyde KD, Corke H, Sun M. 2009 - Molecular phylogenetic identification of endophytic fungi isolated from three Artemisia species. Fungal Divers 36, 6988.

Ignjatov M, Milošević D, Nikolić Z, Varga JG, Jovičić D, Zdjelar G. 2012 - Fusarium oxysporum as causal agent of tomato wilt and fruit rot. Pestic Phytomed (Belgrade) 27, 25-3. doi:10.2298/PIF1201025I.

Jeewon R, Wang HK, Ittoo J, Liu AR, Mahadeb D, Jaufeerally-Fakim Y. 2013 - DNA Based Identification and Phylogenetic Characterisation of Endophytic and Saprobic Fungi from 
Antidesma madagascariense, a Medicinal Plant in Mauritius. Journal of Mycology, Article ID 781914, 10 pages.

Kirk P, Cannon PF, Minter DW, Stalpers JA. 2008 - Ainsworth \& Bisby's Dictionary of the Fungi. 10th edn. CAB International, Wallingford, UK.

Kour A, Shawl AS, Rehman S, Sultan P, Qazi PH, Suden P, Khajuria RK, Verma V. 2008 - Isolation and identification of an endophytic strain of Fusarium oxysporum producing podophyllotoxin from Juniperus recurva. World J Microbiol Biotechnol 24, 1115-1121. doi:10.1007/s11274007-9582.

Kusari S, Spiteller M. 2011 - Are we ready for industrial production of bioactive plant secondary metabolites utilizing endophytes? Nat. Prod. Rep. 28, 1203-1207. doi:10.1039/C1NP0030F.

Leslie JF, Summerell BA. 2006 - The Fusarium laboratory manual. Blackwell publishing, USA.

Li LY, Ding Y, Groth I, Menzel KD, Peschel G. 2008 - Pyrrole and indole alkaloids from an endophytic Fusarium incarnatum (HKI00504) isolated from the mangrove plant Aegiceras corniculatum. J Asian Nat Prod Res 10, 775-780. doi: 10.1080/10286020802031106.

Maehara S, Ohashi K, Shibuya H, Simanjuntak P. 2010 - Composition of endophytic fungi living in Cinchona ledgeriana (Rubiaceae). J Nat Med 64, 227-230. doi: 10.1007/s11418-009-0380-2.

Maehara S, Simanjuntak P, Kitamura C, Ohashi K, Shibuya H. 2012 - Bioproduction of Cinchona alkaloids by the endophytic fungus Diaporthe sp. associated with Cinchona ledgeriana. Chem Pharm Bull 60, 1301-1304.

Maehara S, Simanjuntak P, Maetani Y, Kitamura C, Ohashi K, Shibuya H. 2013 - Ability of endophytic filamentous fungi associated with Cinchona ledgeriana to produce Cinchona alkaloids. J Nat Med 67, 421-423. DOI 10.1007/s11418-012-0701-8.

Mostert L, Crous PW, Kang JC, Philips AJL. 2001 - Species of Phomopsis and Libertella sp. occuring on grapevines with specific reference to South Africa: morphological, cultural, molecular and pathological characterization. Mycologia 93, 146-167.

Niekerk JM van, Groenewald, Farr DF, Fourie PH, Hallen F, Crous PW. 2005 - Reassessment of Phomopsis species on grapevines. Australian Plant Pathol 34, 27-39.

O’Donnell K, Cigelink E, Nirenberg HI. 1998 - Molecular systematics and phylogeography of the Gibberella fujikuroi species complex of Fusarium. Mycologia 90, 465-493.

O'Donnell K, Gueidan C, Sink S, Johnston PR, Crous PW, Glenn A, Riley R, Zitomer NC, Colyer P, Waalwijk C, Lee Tv, Moretti A, Kang S, Kim HS, Geiser DM, Juba JH, Baayen RP, Cromey MG, Bithell S, Sutton DA, Skovgaard K, Ploetz R, Corby Kistler H, Elliott M, Davis M, Sarver BA. 2009- A two-locus DNA sequence database for typing plant and human pathogens within the Fusarium oxysporum species complex. Fungal Genet Biol 46, 936-948.

Santos JM, Phillips AJL. 2009 - Resolving the complex of Diaporthe (Phomopsis) species occurring on Foeniculum vulgare in Portugal. Fungal Divers 34, 111-125. doi: $10.3767 / 003158511 \times 603719$.

Santos JM, Vrandečić K, Ćosić J, Duvnjak T, Phillips AJL. 2011 - Resolving the Diaporthe species occurring on soybean in Croatia. Persoonia 27, 9-19. doi: 10.3767/003158511x603719.

Shibuya H, Kitamura C, Maehara S, Nagahata M, Winarno H, Simanjuntak P, Kim H-S, Wataya Y, Ohashi K. 2003 - Transformation of Cinchona alkaloids into 1-N-oxide derivatives by endophytic Xylaria sp. isolated from Cinchona pubescens. Chem Pharm Bull 51, 71-74.

Shiono Y, Tsuchinari M, Shimanuki K, Miyajima T, Murayama T, Koseki T, Laatsch H, Funakoshi T, Takanami K, Suzuki K. 2007 - Fusaristatins A and B, two new cyclic lipopeptides from an endophytic Fusarium sp. J Antibiot 60, 309-316.

Shweta S, Zuehlke S, Ramesha BT, Priti V, Mohana Kumar P, Ravikanth G, Spiteller M, Vasudeva R, Uma Shaanker R. 2010 - Endophytic fungal strains of Fusarium solani, from Apodytes dimidiata E. Mey. ex Arn (Icacinaceae) produce camptothecin, 10-hydroxycamptothecin and 9methoxycamptothecin. Phytochemistry 71, 117-122. Doi:10.1016/j.phytochem.2009.09.030.

Simanjuntak P, Parwati T, Bustanussalam, Prana TK, Wibowo S, Shibuya H. 2002 - Isolasi dan kultivasi mikroba endofit penghasil senyawa alkaloid kinkona dari Cinchona spp. J Mikrobiol Indo 7, 27-30. 
Song CE. 2009 - An Overview of Cinchona Alkaloids in Chemistry. Pp. 1-10, in (ed.) Song CE, Cinchona alkaloids in synthesis and catalysis, ligands, immobilization and organocatalysis, WILEY-VCH Verlag GmbH \& Co. KGaA, Weinheim.

Steenkamp ET, Coutinho TA, Desjardins AE, Marasas WFO, Wingfield MJ. 2002 - Cryptic speciation in Fusarium subglutinans. Mycologia 94, 1032-1043, doi:10.2307/3761868.

Stöver BC, Müller KF. 2010 - TreeGraph 2: Combining and visualizing evidence from different phylogenetic analyses. BMC Bioinformatics 11, 1-9. doi: 10.1186/1471-2105-11-7.

Strobel G, Daisy B. 2003 - Bioprospecting for Microbial Endophytes and Their Natural Products. Microbiol Mol Biol Rev 67, 491-502.

Swofford DL. 2002- PAUP*: Phylogenetic analysis using parsimony (*and other methods), version 4. Sinauer Associates, Sunderland, Massachusetts.

Tamura K, Stecher G, Peterson D, Filipski A, Kumar S. 2013 - MEGA6: Molecular Evolutionary Genetics Analysis version 6.0. Mol Biol Evol 30, 2725-2729. doi: 10.1093/molbev/mst197.

Tayung K, Barik BP, Jha DK, Deka DC. 2011 - Identification and characterization of antimicrobial metabolite from an endophytic fungus, Fusarium solani isolated from bark of Himalayan yew. Mycosphere 2, 203-213.

Thompson SM, Tan YP, Young AJ, Neate1 SM, Aitken EAB, Shivas RG. 2011 - Stem cankers on sunflower (Helianthus annuus) in Australia reveal a complex of pathogenic Diaporthe (Phomopsis) species. Persoonia 27, 80-89. doi: 10.3767/003158511x617110.

Voigt CA, Schäfer C, Salomon S. 2005 - A secreted lipase of Fusarium graminearum is a virulence factor required for infection of cereals. The Plant Journal 42, 364-375.doi: 10.1111/j.1365313X.2005.02377.x.

Walsh JL, Laurence MH, Lieu ECY, Sangalang AE, Burgess LW, Summerell BA, Petrovic T. 2010 Fusarium: two endophytic novel species from tropical grasses of northern Australia. Fungal divers 44, 149-159. doi:10.1007/s13225-010-0035-3.

Watanabe M, Yonezawa T, Lee K, Kumagai S, Konishi YS, Goto K, Kudo YH. 2011 - Molecular phylogeny of the higher and lower taxonomy of the Fusarium genus and differences in the evolutionary histories of multiple genes. Evol Biol 11, 322-338. doi:10.1186/1471-2148-11322.

White TJ, Bruns T, Lee S, Taylor J. 1990 - Amplification and direct sequencing of fungal ribosomal RNA genes for phylogenetics. Pp. 315-322, in MA Innis et al. (eds.), PCR Protocols: a guide to methods and applications. San Diego, Academic Press.

Wijnsma R, Verpoorte R. 1988 - Quinoline alkaloids of Cinchona. Cell Culture and Somatic Cell Genetics of Plants 5, 335-35. 